\title{
Larval development of the brachiopod Coptothyris grayi (Davidson, 1852) (Terebratulida: Rhynchonelliformea) and the evolution of brachiopod life cycles
}

\author{
T.V. Kuzmina, V.V. Malakhov, E.N. Temereva \\ Lomonosov Moscow State University, Vorobievi gory 1-12, Moscow 119991 Russia. \\ E-mail:kuzmina-t@yandex.ru
}

ABSTRACT: Larval development of the brachiopod Coptothyris grayi (Davidson, 1852) (Terebratulida: Rhynchonelliformea) is investigated with scanning electron microscopy and confocal laser scanning microscopy. At the early larval stage, the mantle rudiment forms obliquely to the anteroposterior axis of the larva: its dorsal side is located closer to the larval apical lobe than its ventral side. Young three-lobed larvae exhibit three pairs of coelomic pouches: one pair in the apical lobe and two pairs in the mantle lobe. The number of coelomic pouches in the mantle lobe of the larvae corresponds to the number of bundles of setae. At the early larval stage, the dorsal pair of bundles of setae is located closer to the larval apical lobe than the lateral pair, whereas in full-grown larvae, both pairs of bundles of setae are at the same level. This means that the dorsal side of the mantle grows faster at the late larval stage. We analyze the data on the development of extant brachiopods and propose a hypothesis on the evolution of brachiopod life cycles. The ancestral brachiopod had a pelago-benthic life cycle with a ciliary planktotrophic larva (not to be confused with the shelled planktotrophic juvenile of recent lingulids) that folded during metamorphosis. The next evolutionary stage was the transition from planktotrophy to lecithotrophy, but the lecithotrophic larvae of recent brachiopods are not homologous. Recent craniiforms retain the true unfolded lecithotrophic larvae. The full-grown lecithotrophic larva of recent rhynchonelliforms corresponds to the folded juvenile that ascends into the water column. The pelagic life cycle phase of recent discinids comprises the lecithotrophic larva that corresponds to the folded stage and the shelled planktotrophic stage that is essentially the juvenile ascended into the water column. As for recent lingulids, their life cycle is characterized by the embryonization of all developmental stages except the shelled planktotrophic juvenile. Accordingly, the lingulid life cycle is the most modified among all recent brachiopods.

How to cite this article: Kuzmina T.V., Malakhov V.V., Temereva E.N. 2019. Larval development of the brachiopod Coptothyris grayi (Davidson, 1852) (Terebratulida: Rhynchonelliformea) and the evolution of brachiopod life cycles // Invert. Zool. Vol.16. No.1. P.27-40. doi: 10.15298/invertzool. 16.1.04

KEY WORDS: brachiopods, Rhynchonelliformea, Coptothyris grayi, larval development, life cycle, evolution. 


\title{
Личиночное развитие брахиоподы Coptothyris grayi (Davidson, 1852) (Terebratulida: Rhynchonelliformea) и эволюция жизненных циклов брахиопод
}

\author{
Т.В. Кузьмина, В.В. Малахов, Е.Н. Темерева
}

Кафедра зоологии беспозвоночных, Биологический факультет МГУ имени М.В. Ломоносова, Ленинские горы 1-12, Москва 119991 Россия. E-mail: kuzmina-t@yandex.ru

РЕЗЮМЕ: Изучено личиночное развитие брахиоподы Coptothyris grayi (Davidson, 1852) (Terebratulida: Rhynchonelliformea) методами сканирующей и конфокальной электронной микроскопии. У ранней личинки зачаток мантии формируется косо относительно ее передне-задней оси: дорсальная сторона мантийного зачатка сдвинута к переднему концу личинки, а вентральная сторона сдвинута к заднему концу личинки. У ранних трехлопастных личинок имеются три пары целомических мешков: одна пара расположена в апикальной лопасти, остальные две пары в мантийной лопасти. Число целомических мешков в мантийной лопасти соответствует числу пучков щетинок. У ранних личинок дорсальная пара пучков щетинок расположена ближе к апикальной лопасти, в то время как латеральная пара смещена назад. Дальнейшее развитие личинки сопровождается разрастанием дорсального сектора мантии и смещением назад дорсальной пары пучков щетинок. В результате у компетентной личинки две пары пучков щетинок располагаются на одном уровне. На основе анализа литературных данных по развитию современных брахиопод предложена гипотеза эволюции их жизненных циклов. Предок брахиоподы имел пелаго-бентический жизненный цикл с ресничной планктотрофной личинкой (просьба не путать с планктотрофной ювенилью современных лингулид), которая складывалась при оседании. Следующий эволюционный шаг был связан с переходом от планктотрофии к лецитотрофии, однако лецитотрофные личинки современных брахиопод не гомологичны друг другу. Современные кранииформные брахиоподы сохранили не сложенную лецитотрофную личинку. Компетентная лецитотрофная личинка замковых брахиопод соответствует сложенной ювенили кранииподобного предка, которая поднялась в толщу воды. У дисцинид из яйца вылупляется лецитотрофная личинка, которая вскоре становится планктотрофной стадией, покрытой раковиной. Обе планктонные стадии дисцинид являются поднятыми в толщу воды ювенилями кранииподобного предка. Современные лингулиды характеризуются эмбрионизацией всех стадий развития, кроме планктотрофной ювенили, покрытой раковиной. Таким образом, жизненный цикл современных лингулид является наиболее продвинутым среди брахиопод.

Как цитировать эту статью: Kuzmina T.V., Malakhov V.V., Temereva E.N. 2019. Larval development of the brachiopod Coptothyris grayi (Davidson, 1852) (Terebratulida: Rhynchonelliformea) and the evolution of brachiopod life cycles // Invert. Zool. Vol.16. No.1. P.27-40. doi: 10.15298/invertzool. 16.1.04

КЛЮЧЕВЫЕ СЛОВА: Брахиоподы, Rhynchonelliformea, Coptothyris grayi, личиночное развитие, жизненный цикл, эволюция. 


\section{Introduction}

Brachiopoda is a relict and highly variable group of marine invertebrates with pelago-benthic life cycle that includes planktonic floating and sessile attached stages. The brachiopods are subdivided into three subphyla, Linguliformea, Craniiformea and Rhynchonelliformea (Williams et al., 1996). These three phylogenetic branches separated from each other at the early stage of brachiopod evolution and strongly differ in major aspects of shell morphology and soft body anatomy (Harper et al., 2017). All brachiopods have a pelago-benthic life cycle that is typical of many marine invertebrates. Nonetheless, the life cycles of representatives of various brachiopod subphyla can vary dramatically. Numerous studies have shown a great variety in the structure of the brachiopod larvae and the pathways of their metamorphosis (Kovalevsky, 1874, 1883; Conklin, 1902; Yatsu, 1902; Percival, 1944, 1960; Malakhov, 1976, 1983; Chuang, 1977, 1996; Nielsen, 1991; Long, Stricker, 1991; Freeman, 1993, 1995, 1999, 2000, 2003; Lüter, 2000; Altenburger, Wanninger, 2009; Zakrzewski et al., 2012; Altenburger et al., 2013, 2017; Santagata, 2015; Martín-Durán et al., 2016; Vellutini, Heinol, 2016; Gąsiorowski, Hejnol, 2019). This raises the question as to which type of life cycle is the most primitive and whether it is possible to propose any general scheme of the evolution of life cycles within the phylum.

The present research studies the larval development of the rhynchonelliform brachiopod Coptothyris grayi (Davidson, 1852), analyzes the data on the ontogeny of recent brachiopods, and proposes a hypothesis on the evolution of brachiopod life cycles.

\section{Material and methods}

We used the artificial insemination method to study the development of C. grayi. Mature specimens were collected in July 2016 at a depth of 8-10 $\mathrm{m}$ in Vostok Bay in the Sea of Japan. Insemination and developmental stages were observed in the embryology laboratory of the marine biological station "Vostok" of the National Scientific Centre of Marine Biology, Far Eastern Branch, Russian Academy of Science. The male and female gonads of $C$. grayi are located in the mantle coelomic canals. In order to obtain the gametes, the adductors were cut and the valves were opened. The oocytes and the sperm were obtained by Pasteur pipette from ovary and testis, respectively. The oocytes were washed with two changes of filtered sea water and were kept at $18^{\circ} \mathrm{C}$ for $5 \mathrm{~h}$ for shedding of the follicle cells and breakdown of germinal vesicles in the eggs. The sperm was kept for 15 min. Sperm motility was monitored by light microscopy. Five milliliters of sperm suspension were added to $300 \mathrm{ml}$ of filtered sea water with the eggs. In one hour, the zygotes were washed three times with filtered sea water. The embryos and larvae were kept in vessels at a concentration of 1 larva per $3 \mathrm{~mm}^{3}$ of water $\left(18^{\circ} \mathrm{C}\right)$. The water was refreshed twice a day.

For scanning electron microscopy (SEM), the consecutive developmental stages were fixed in $2.5 \%$ cacodylate-buffered glutaraldehyde. The material was further treated using standard scanning electron microscopy techniques. The samples were examined and photographed using Hitachi S-405A (Hitachi, Japan) and CamScan S2 (Cambridge Instruments, United Kingdom) scanning electron microscopes.

For confocal laser scanning microscopy (cLSM), the early three-lobed larvae (23 h after insemination) were fixed overnight in a $4 \%$ paraformaldehyde solution in filtered sea water and washed two times in phosphate buffer (pH7.4) (Fisher Scientific, Pittsburgh, PA, USA) with Triton X-100 (0.3\%) (Fisher Scientific) for a total of $12 \mathrm{~h}$. Non-specific binding sites were blocked with $10 \%$ normal donkey serum (Jackson ImmunoResearch, Newmarket, Suffolk, UK) in phosphate buffer (PBS) with Triton X-100 (PBT) overnight at $4^{\circ} \mathrm{C}$. The larvae were then placed in PBT and incubated in rhodamineconjugated phalloidin (1:50) (Fisher Scientific, Pittsburgh, PA, USA) for $2 \mathrm{~h}$ at room temperature in the dark. They were subsequently washed in PBS (three times x $60 \mathrm{~min}$ ), mounted on a cover glass covered with poly-1-lysine (Sigma- 
Aldrich, St. Louis, MO, USA), and embedded in Murray Clear. Specimens were examined with a Nikon Eclipse Ti confocal microscope (Moscow State University, Moscow, Russia). Z-projections were generated using the program Image $\mathrm{J}$ version 1.43 .

\section{Results}

The ciliated blastula hatches from the egg envelope $6 \mathrm{~h}$ after fertilization. It lifts from the bottom and starts to swim, rotating on its axis. The gastrula starts to form about $11 \mathrm{~h} 30 \mathrm{~min}$ after fertilization. The gastrulation occurs by invagination. The round blastopore forms on the vegetative pole of the embryo and thus the first-formed gastrula has a radial symmetry (Fig. 1A). About 16 h $30 \mathrm{~min}$ after fertilization, the blastopore elongates and the apical pole shifts anteriorly. Thus, the gastrula becomes bilateral (Fig. 1B).

At $19 \mathrm{~h}$ after fertilization, the first constriction divides the apical and posterior lobes of the larva. The rudiment of the mantle lobe appears under the apical lobe about $23 \mathrm{~h}$ after fertilization, so the larva at this stage consists of the apical, mantle and pedicle lobes (Fig. 1C-D). The blastopore becomes elongated into a droplike shape (Fig. 1C). Note that the larval mantle rudiment develops obliquely relative to the anteroposterior axis of the larva: its dorsal side is located closer to the larval apical lobe than its ventral side (Fig. 1D). At this stage, the apical organ and ciliary band form on the apical lobe. Groups of small vesicular bodies form around the apical lobe.

At $26 \mathrm{~h}$ after fertilization, the mantle lobe enlarges but remains inclined to the anteroposterior axis (Fig. 1E, G). Two pairs of short setae bundles form at this stage. One pair is located on the dorsal side of the mantle, while another pair is located on the lateral sides of the mantle (Fig. $1 G)$. The setal bundles are obliquely arranged (the first dorsal pair is shifted anteriorly, the second lateral pair is shifted posteriorly) (Fig. $1 \mathrm{E})$. The group of eyespots appears on the apical lobes. The blastopore starts to close from the posterior end; a small depression remains on the apical lobe at the position of the blastopore anterior end (Fig. 1F).

At $45 \mathrm{~h}$ after fertilization, the full-grown three-lobed larva is formed (Fig. 1H). The blastopore is completely closed. The mantle is skirtlike shaped and surrounds the pedicle. The ventral part of the mantle is somewhat longer than the dorsal part. The longitudinal ciliary band runs along the ventral part of the mantle lobe. Two pairs of long spinose setae are located at the mantle margin at the same level. The pedicle becomes constricted in the middle.

We studied a young larva (about $23 \mathrm{~h}$ after fertilization) using confocal microscopy with phalloidin staining. The elongated drop-like blastopore is clearly visible at the ventral side of the larva (Fig. 2A). The wide anterior end of the blastopore is in front of the border between the apical and mantle lobes, whereas its tapering posterior end reaches the pedicle lobe. The mesodermal precursor is horseshoe-shaped (Fig. 2B). Both branches of the horseshoe are connected to each other in front of the intestine. The mesoderm forms three pairs of coelomic pouches on both sides of the archenteron. The coelomic pouches of the anterior pair are in the apical lobe; they are connected to each other by a mesodermal strand in front of the archenteron. The second and the third pairs of coelomic pouches are in the mantle lobe on both side of the archenteron (Fig. 2B).

\section{Discussion}

As outlined above, brachiopods are characterized by great diversity in larval structure and metamorphosis pathways. In our opinion, the most primitive features should be sought in the development of craniiform brachiopods. In a thoroughly studied recent craniiform brachio-

Обозначения: acb - pесничный шнур на апикальной лопасти, al — апикальная лопасть, bl — бластопор, dm — дорсальная часть мантийной лопасти, mcb - ресничный шнур на мантийной лопасти, ml — мантийная лопасть, $\mathrm{pl}$ - ножная лопасть, se - щетинки, vb - везикулярные тельца, vm - вентральная часть мантийной лопасти. 

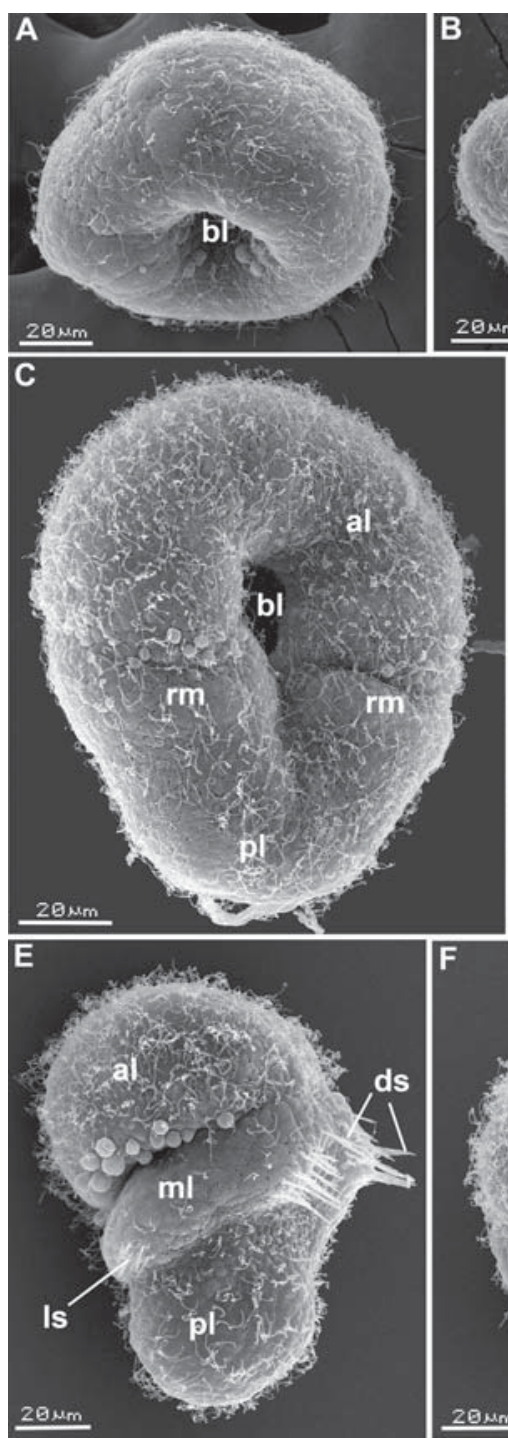
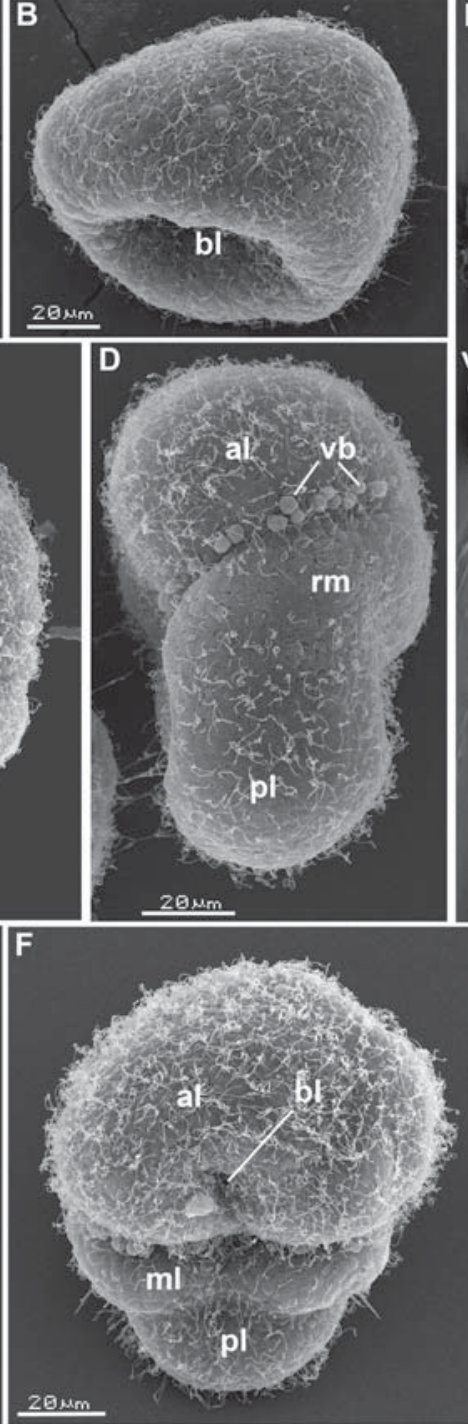
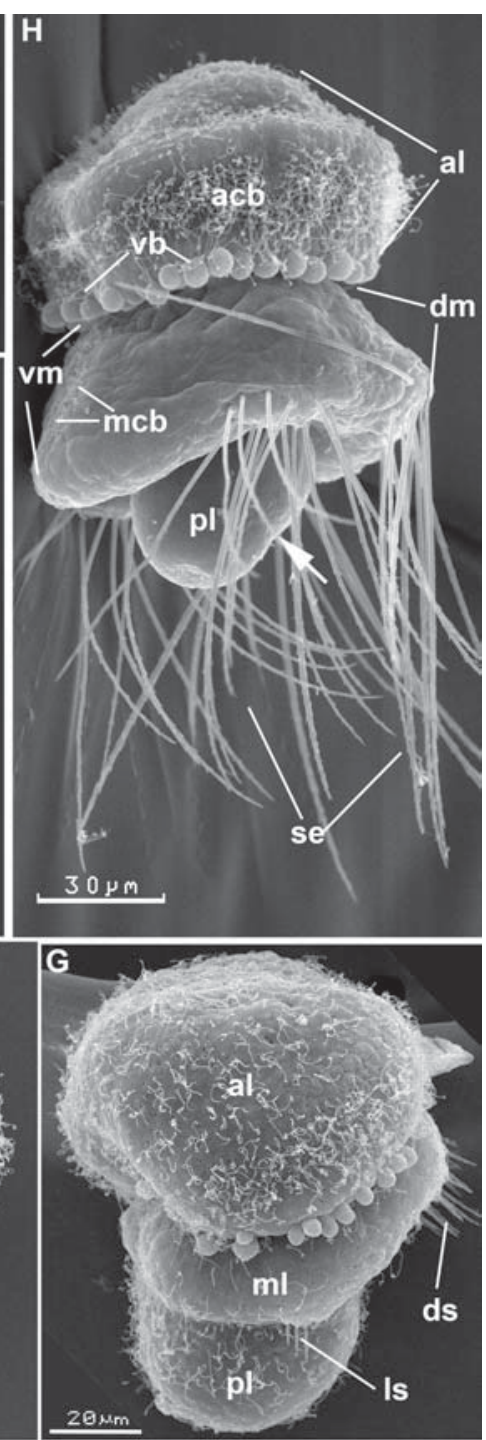

Fig. 1. Larval development of Coptothyris grayi (SEM). A — radially symmetric gastrula ( $\sim 15 \mathrm{~h}$ after fertilization); B - bilateral gastrula ( $\sim 17 \mathrm{~h}$ after fertilization); C-D - early larva with rudiment of mantle lobe $(\mathrm{rm})(\sim 23 \mathrm{~h}$ after fertilization): $\mathrm{C}$ - ventral view, $\mathrm{D}$ - lateral view; $\mathrm{E}-\mathrm{G}$ - young three-lobed larva ( $\sim 27 \mathrm{~h}$ after fertilization): $\mathrm{E}$ - lateral view, pair of dorsal setal bundles (ds), F — ventral view, $\mathrm{G}$ - lateral view, lateral setal bundle (ls); $\mathrm{H}-$ full-grown larva ( $45 \mathrm{~h}$ after fertilization).

Abbreviations: acb - ciliary band on apical lobe, al — apical lobe, $\mathrm{bl}$ - blastopore, $\mathrm{dm}$ - dorsal part of mantle lobe, $\mathrm{mcb}$ - ciliary band on mantle lobe, $\mathrm{ml}$ - mantle lobe, $\mathrm{pl}$ - pedicle lobe, se - setae, vb - vesicular bodies, $\mathrm{vm}$ ventral part of mantle lobe.

Рис. 1. Личиночное развитие of Coptothyris grayi (СЭМ). А - радиально симметричная гаструла (около 15 ч после оплодотворения); В - билатерально симметричная гаструла (около 17 ч после оплодотворения); C-D - ранняя личинка с зачатком мантийной лопасти (rm) (около 23 ч после оплодотворения): C - вид с вентральной стороны, D - вид сбоку; $\mathrm{E}-\mathrm{G}$ - ранняя трехлопастная личинка (около 27 ч после оплодотворения): $\mathrm{E}$ - вид сбоку, видна пара дорсальных пучков щетинок (ds), F — вид с вентральной стороны, G - вид сбоку, виден пучок латеральных щетинок (ls); H компетентная личинка (около 45 ч после оплодотворения). 

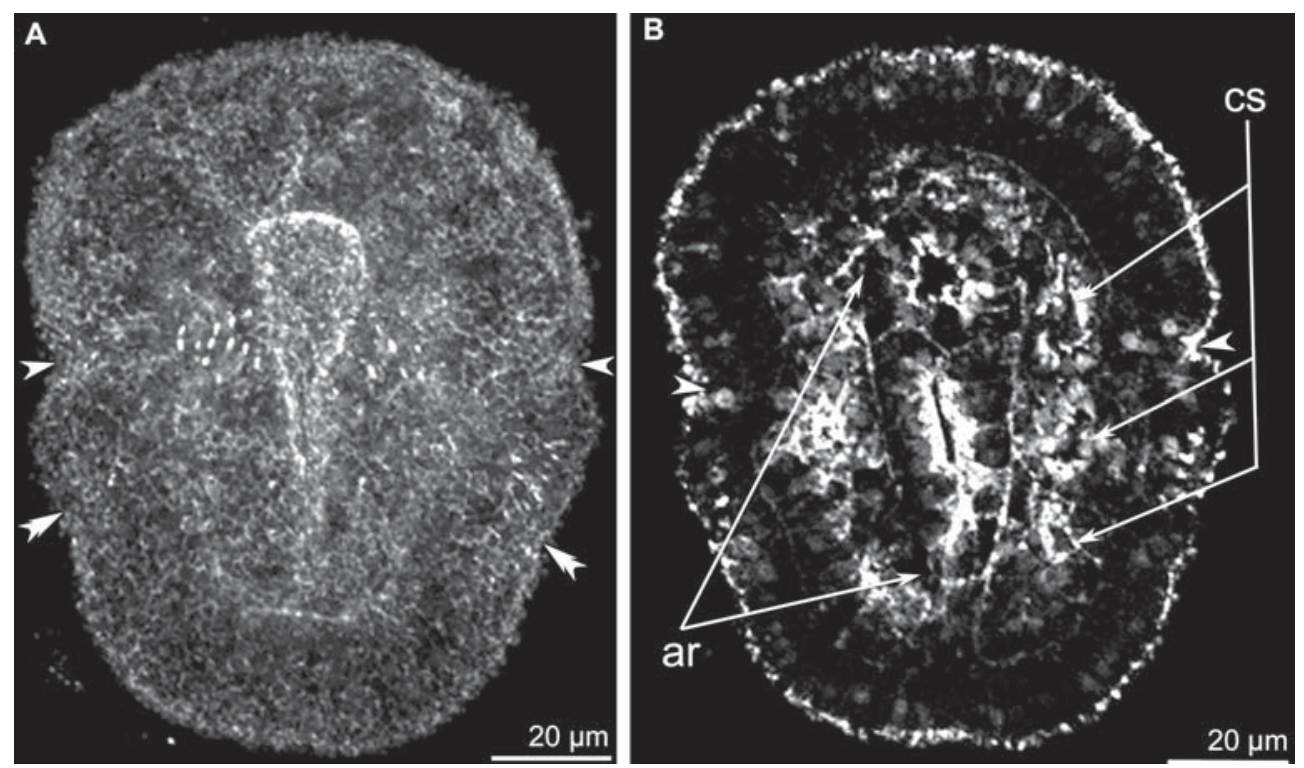

Fig. 2. Z-projections of early larva of Coptothyris grayi ( $\sim 23 \mathrm{~h}$ after fertilization) after staining with phalloidin. A - ventral view of early larva, drop-shaped blastopore is visible; B - Z-projection of 51-52 slides of the stack, coelomic pouches visible at left side of larva.

Abbreviations: ar - archenteron, cs - coelomic pouches, arrows indicate the first constriction between apical lobe and rudiment of mantle lobe, double arrows indicate the second constriction between rudiment of mantle lobe and pedicle lobe.

Рис. 2. Z-проекции ранней личинки Coptothyris grayi (около 23 ч после оплодотворения) при окрашивании фаллоидином. А - вид с вентральной стороны на раннюю личинку, виден каплевидный бластопор; В - Z-проекция 51-52 слайдов стэка, видны целомические мешки с левой стороны личинки.

Обозначения: ar - архентерон, cs — целомические мешки, стрелки указывают на перетяжку между апикальной лопастью и зачатком мантии, двойные стрелки указывают на перетяжку между зачатком мантии и ножной лопасти.

pod, Novocrania anomala (O. F. Müller, 1776), the ciliary blastula hatches from the egg envelope, so that the gastrulation and formation of lecithotrophic larva proceed in the water column (Nielsen, 1991). The larva swims for about four days. The competent larva is subdivided into two lobes, the rounded 'head' and dorsoventrally flattened 'body' (Fig. 3A-B). The wide, densely ciliated band delimits the head lobe posteriorly. The 'body' bears cilia on the ventral, lateral, and posterior sides. The larva of $N$. anomala demonstrates a clear metamery, which is expressed externally by the presence of three pairs of bundles of setae (Fig. 3A-B). The mesodermal precursor is subdivided into four pairs of coelomic pouches (Fig. 3E). The pouches of the anterior pair are in the head lobe; they are connected to each other by a mesodermal strand in front of the archenteron (Nielsen, 1991). The body lobe contains three pairs of coelomic pouches associated with the setal sacs (Fig. 3E). The precursor of the brachial valve is a round shield of modified cuticle on the dorsal side of the body lobe (Fig. 3A).

Upon settling, the larva curls ventrally through muscle contraction (Fig. 3C). The larva is then attached to the substratum, and the attachment site corresponds to the area of the dorsal side behind the brachial valve precursor (Fig. 3F). In metamorphosis, the third pair of setae is shed. The brachial valve precursor grows rapidly, and the attached juvenile becomes cov- 


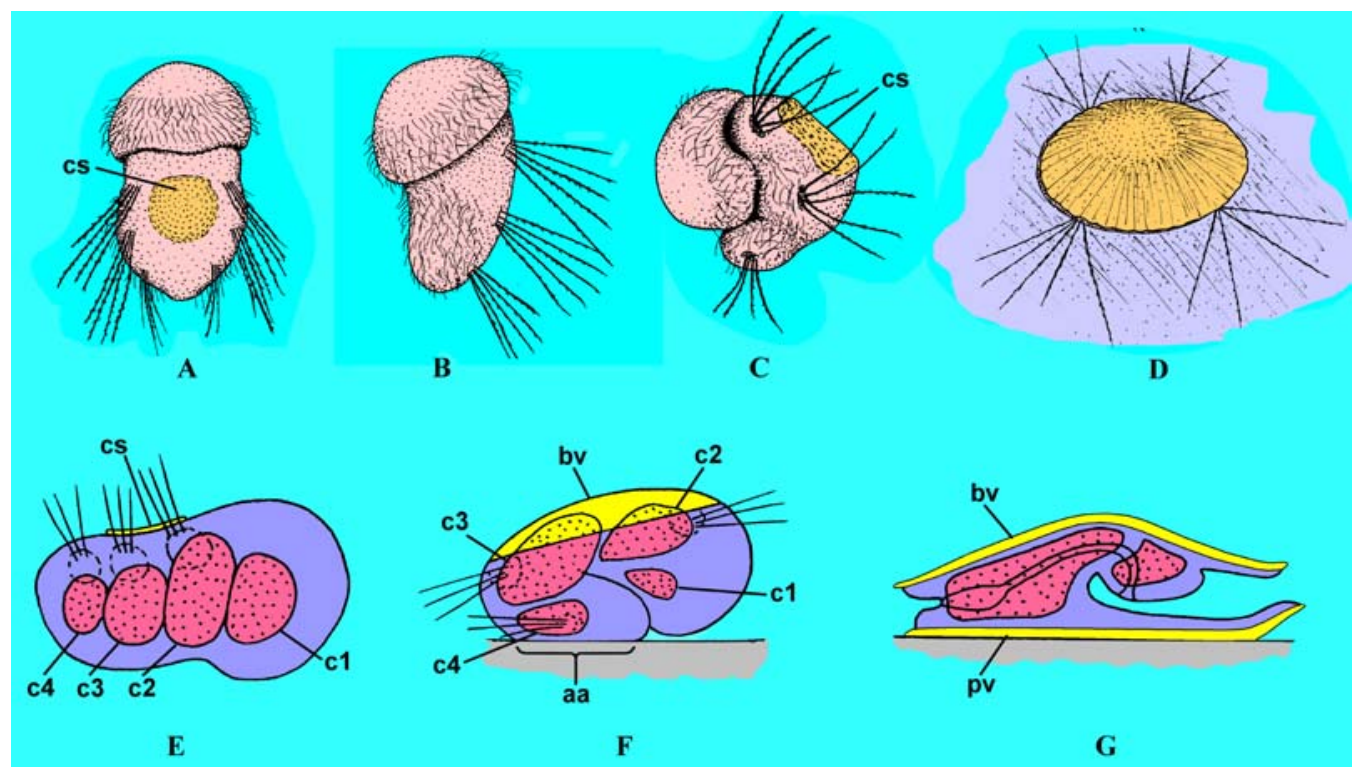

Fig. 3. The larva and metamorphosis of Novocrania anomala (based on Nielsen, 1991, 2001). A - fullgrown larva, dorsal view; B - the same, lateral view; C — folding larva, lateral view; D — juvenile about 3 days after settling; $\mathrm{E}$ - arrangement of coelomic sacs and setae in full-grown larva; $\mathrm{F}$ - arrangement of coelomic sacs and setae in young bottom stage; $\mathrm{G}$ - structure of the juvenile with two shell valves.

Abbreviations: aa - attachment area, bv — brachial ("dorsal") valve, c1-c4 - coelomic sacs, cs - cuticular shield, the brachial valve precursor, pv - pedicle ("ventral") valve.

Рис. 3. Личинка и метаморфоз Novocrania anomala (по данным Nielsen, 1991, 2001). А — компетентная личинка, вид с дорсальной стороны; В - компетентная личинка, вид сбоку; С - сложенная личинка, вид сбоку, D - ювениль около 3 дней после оседания; Е - расположение целомических мешков и пучков щетинок у компетентной личинки; F - расположение целомических мешков и пучков щетинок у осевшей стадии; $\mathrm{G}$ - строение ювенили с двумя створками раковины.

Обозначения: aa - область прикрепления, bv - брахиальная («дорсальная») створка, c1-c4 - целомические мешки, cs - область, покрытая кутикулой, зачаток брахиальной створки, pv — педальная («вентральная») створка.

ered with the brachial valve (Fig. 3D). The pedicle valve, in contrast, is secreted much later by the epithelium of the attachment area (Fig. $3 \mathrm{G}$ ). Based on the foregoing, both valves are secreted by the dorsal epithelium of the larva, though not at the same time. Accordingly, both valves are essentially dorsal, with the brachial valve in front, the pedicle valve in back.

The "folding" during the metamorphosis of craniids provides the basis for the "brachiopodfold hypothesis" (Nielsen, 1991). The metamorphosis of recent craniids is considered to be a recapitulation of the brachiopod body plan origin. Initially, folding might have been merely a feature of behavior, a kind of defensive habit.
One may speculate that the supposed creeping ancestor had two dorsal protective shells arranged one behind the other (Fig. 4). During a predator attack, the brachiopod ancestor curled ventrally in the same way that extinct trilobites did and extant chitons do. Later, the folding condition was fixed as a permanent feature because it helped protect the soft body with two valves.

According to Altenburger et al. (2013), the dorsal (=brachial) mantle forms during metamorphosis and the ventral (=pedicle) mantle develops 17 days after metamorphosis. Altenburger et al. (2013) believe that the secretion of both valves on the dorsal side of larva is not 


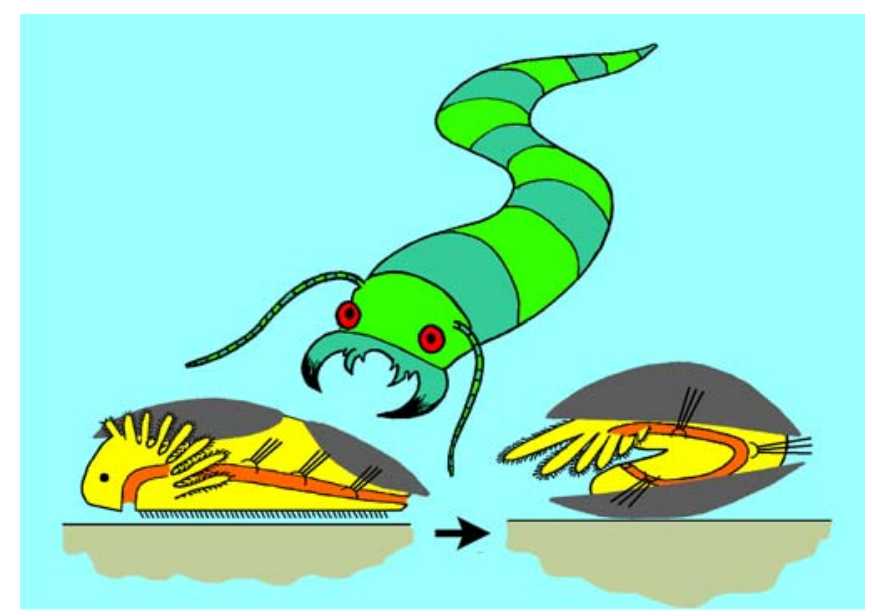

Fig. 4. Protective habit became the basis for the emergence of the brachiopod body plan.

Рис. 4. Формирование плана строения брахиопод в результате защитного поведения их предка.

proved, although those authors definitely described the ventral curvature of the larva at settling: "The anterior lobe and the posterior end of the posterior lobe are bent ventrally, thus exposing the dorsal posterior lobe to the environment" (Altenburger etal., 2013, p. 381). The "brachiopod fold hypothesis" has been the subject of criticism based on developmental gene expression data (Altenburger et al., 2013; Martín-Durán et al., 2016; Altenburger et al., 2017). The expression patterns of developmental genes in the larva of $N$. anomala show that "anterior" genes are expressed in the anterior lobe and "posterior" genes are expressed in the posterior domain of the posterior lobe (Martín-Durán et al., 2016; Altenburger et al., 2017). Importantly, however, these data are relevant to the unbent larva, so they cannot be considered as a convincing argument against the "brachiopodfold hypothesis".

According to the "brachiopod-fold hypothesis", the supposed brachiopod ancestor had a life cycle with a planktotrophic larva equipped with ciliary bands that is typical for benthic invertebrates. After settling, the larva curls on the ventral side (Fig. 5A). The craniid-like life cycle evolved from the ancestral one, with the difference that the larva lost the primary planktotrophy and became lecithotrophic (Fig. 5B). The delay in the formation of the pedicle valve versus brachial valve is apparently an apomorphy of recent craniiform brachiopods (Fig. 5C). The rapid growth and differentiation of the brachial valve is explained by the important role the brachial valve plays in protecting the attached juveniles.

The development and metamorphosis of Rhynchonelliformea are described in several classical and contemporary works (Kovalevsky, 1874, 1883; Conklin, 1902; Percival, 1944, 1960; Malakhov, 1976, 1983; Chuang, 1996; Freeman, 1993, 2003; Lüter, 2000; Altenburger, Wanninger, 2009; Zakrzewski et al., 2012; Vellutini, Heinol, 2016; Gąsiorowski, Hejnol, 2019). The full-grown larva of Rhynchonelliformea is subdivided into three lobes: the apical, mantle, and pedicle ones. Our data relating to $C$. grayi enable us to convincingly prove that the rudiment of the mantle lobe forms obliquely to the anteroposterior axis of the larva. The mantle lobe increases in size by growth of its dorsal sector (Fig. 6D-E). The full-grown larva has a skirt-like mantle lobe that is located perpendicular to the anteroposterior axis of the larva. The growth of the dorsal mantle is accompanied by the posterior displacement of the dorsal pair of setal bundles.

Our data demonstrate the rhynchonelliform C. grayi has one pair of coelomic pouches in the apical lobe and two pairs of coelomic pouches 

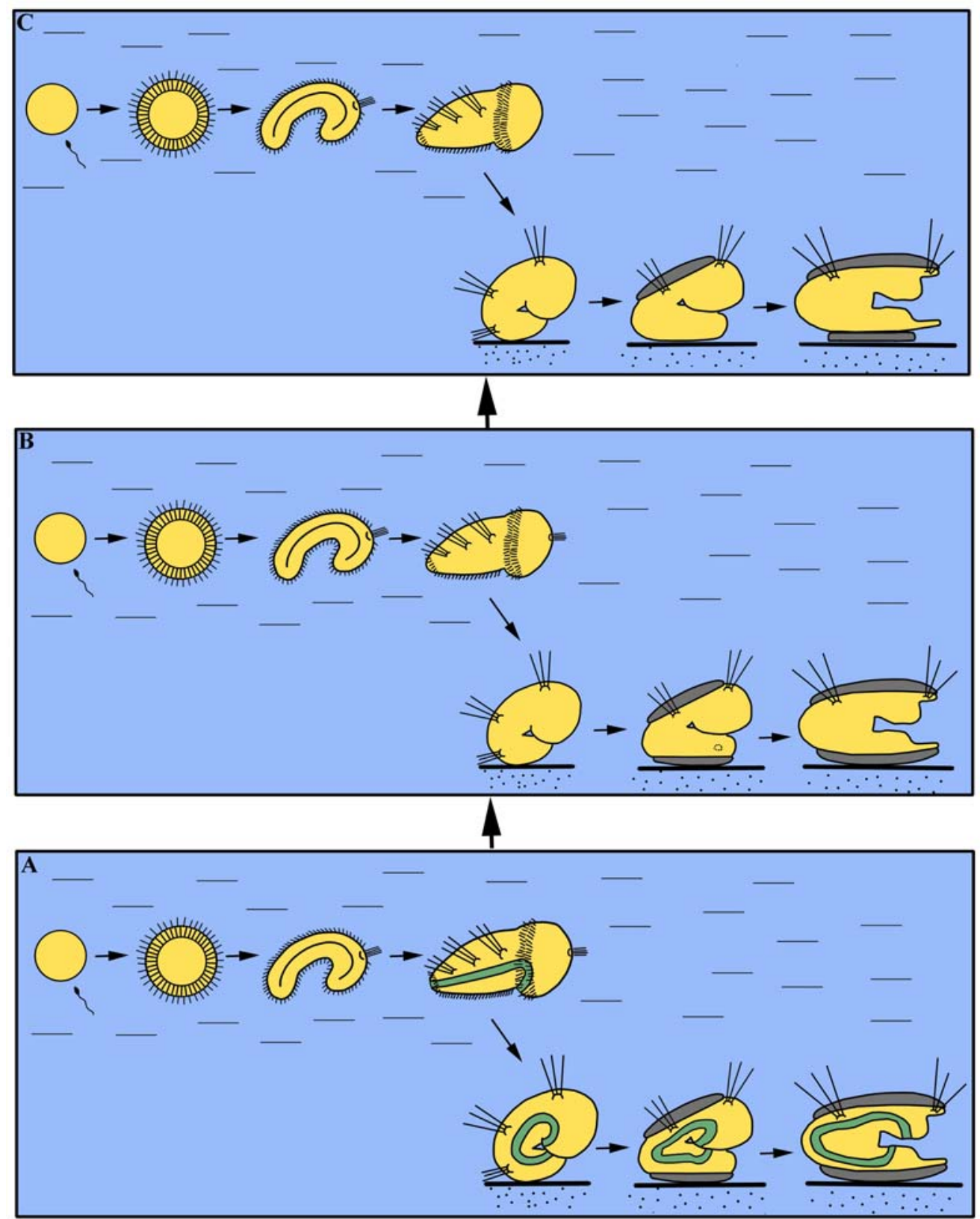

Fig. 5. Evolutionary origin of the life cycle of recent craniids from the primary brachiopod life cycle. A primary life cycle of supposed brachiopod ancestor with planktotrophic larva; B - craniid-like life cycle with lecithotrophic larva; C - life cycle of recent craniid (e.g. Novocrania anomala) with lecithotrophic larva and delay of the ventral valve formation (by Nielsen, 1991; Altenburger et al., 2013).

Рис. 5. Происхождения жизненного цикла краниил от первичного жизненного цикла брахиопод. А первичный жизненный цикл предполагаемого предка брахиопод с планктотрофной личинкой; В краниидоподобный жизненный цикл с лецитотрофной личинкой; $\mathrm{C}$ - жизненный цикл современных краниид (на примере Novocrania anomala) с лецитотрофной личинкой (по Nielsen, 1991 и Altenburger et al., 2013). 


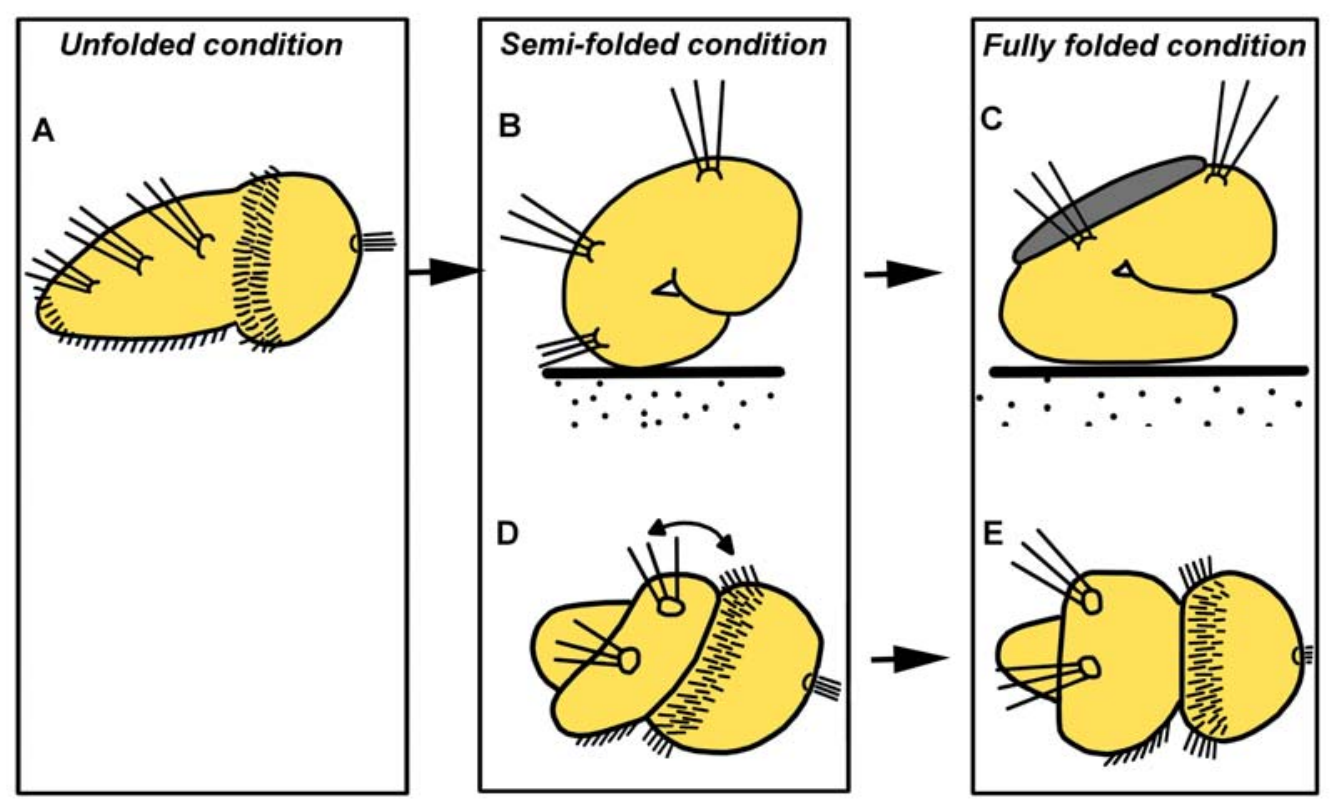

Fig. 6. Correlation between craniid-like and rhynchonelliform developmental stages. A — craniid-like fullgrown larva; B - craniid-like semi-folding juvenile; $\mathrm{C}$ - craniid-like completely folded juvenile; D early three-lobed larva of rhynchonelliform brachiopod; E - full-grown larva of rhynchonelliform brachiopod.

Рис. 6. Соотношение между краниидоподобными и ринхонеллиформными стадиями развития. А краниидоподобная компетентная личинка; В - краниидоподобная полусложенная ювениль; С краниидоподобная полностью сложенная ювениль; D - ранняя трехлопастная личинка ринхонеллиформной брахиоподы; Е — компетентная личинка ринхонеллиформной брахиоподы.

in the mantle lobe. The number of coelomic sacs in the mantle lobe of the larva corresponds to the number of setal bundles. The mesoderm of the craniiform $N$. anomala forms four pairs of coelomic pouches: one pair in the anterior lobe and three pairs in the posterior lobe. The posterior lobe bears three pairs of the setal bundles. Importantly, the coelothelium of coelomic pouches forms the muscles of the setal bundles (Nielsen, 1991). In the craniid larva, however, the coelomic pouches and bundles of setae are successively arranged along the anteroposterior axis, whereas in the early three-lobed larva of the rhynchonelliform $C$. grayi, the coelomic pouches and setal bundles are obliquely arranged on the dorsal and lateral sides (Fig. 6D). Our conclusion is that the young larva of $C$. grayi with oblique rudiment of the mantle lobe corresponds to the larva of $N$. anomala in a semi-folded condition (Fig. 6B). The mantle lobe increases in size by growth of its dorsal sector; a fully developed larva of $C$. grayi corresponds to the fully folded juvenile of $N$. anomala (Fig. 6C, E).

Accordingly, the recent rhynchonelliform life cycle evolved from the craniid-like life cycle by transformation of semi-folded and fully folded settled stages into the planktonic larvae and, thus, the folding of recent rhynchoneliforms occurs at the floating stages (Fig. 7). The formation of the mantle fold in the inverted position at the plankton stage and its reversion to the normal position after settling seems to be an autopomorhy of recent rhynchonelliforms. It is unrelated to the folding. Note that the larva of $N$. anomala sheds the third pair of bundles of setae after settling, and thus the settled larva of $N$. anomala and planktonic larva of C. grayi 


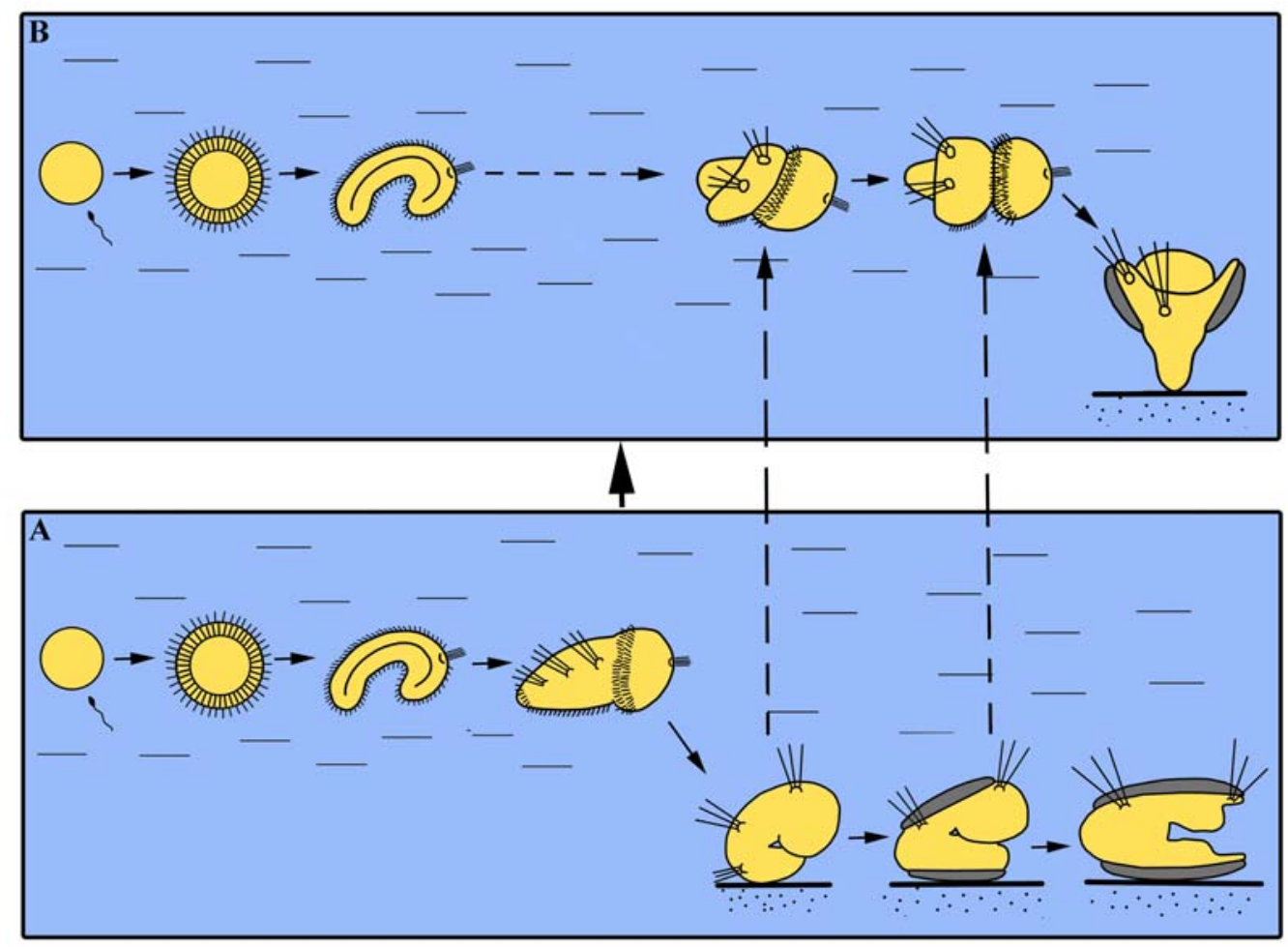

Fig. 7. Origin of the recent rhynchonelliform life cycle. A — ancestral craniid-like life cycle; B — recent rhynchonelliform life cycle.

Рис. 7. Происхождение жизненного цикла современных ринхонеллиформных брахиопод. А краниидоподобный жизненный цикл; В - жизненный цикл современных ринхонеллиформных брахиопод.

have an equal number of the bundles. Therefore, the data on the development of recent rhynchonelliforms is actually an argument in favor of the "brachiopod-fold hypothesis".

Recent linguliforms are represented by two families, discinids and lingulids, which differ with regard to larval development. In recent discinids, newly hatched larvae have neither a mouth nor anus (Freeman, 1999; Lüter, 2001). The larva consists of anterior and posterior lobes and bears three long larval setae on each side of the two-lobed lecithotrophic larva. At the present level of our knowledge, it is difficult to determine whether the setae of the same side are combined into one setal bundle, although Chuang depicted them as combined in one "setal cone" (Chuang, 1977, fig. 1, B). At a later stage, the mouth, anus, two-valved shell, and lophophore tentacles form (Freeman, 1999; Chuang, 1977; Lüter, 2001). From that moment on, this stage becomes planktotrophic. We interpret these findings to mean that the two-lobed discinid larva corresponds to the folded stage of the recent craniids that continues to float (Fig. 8A-B). As for the planktotrophic stage with lophophore and shell, it corresponds to the settled juvenile of recent craniids with the shell, but in discinids this stage lives in the water column (Fig. 8A-B). Accordingly, the life cycle of recent discinids originated from the craniidlike one due to the movement of early benthic juveniles into the water column.

In recent lingulids, the newly hatched larva has the two-valved shell and lophophore and feeds on plankton (Yatsu, 1902). All previous developmental stages are compressed under the 


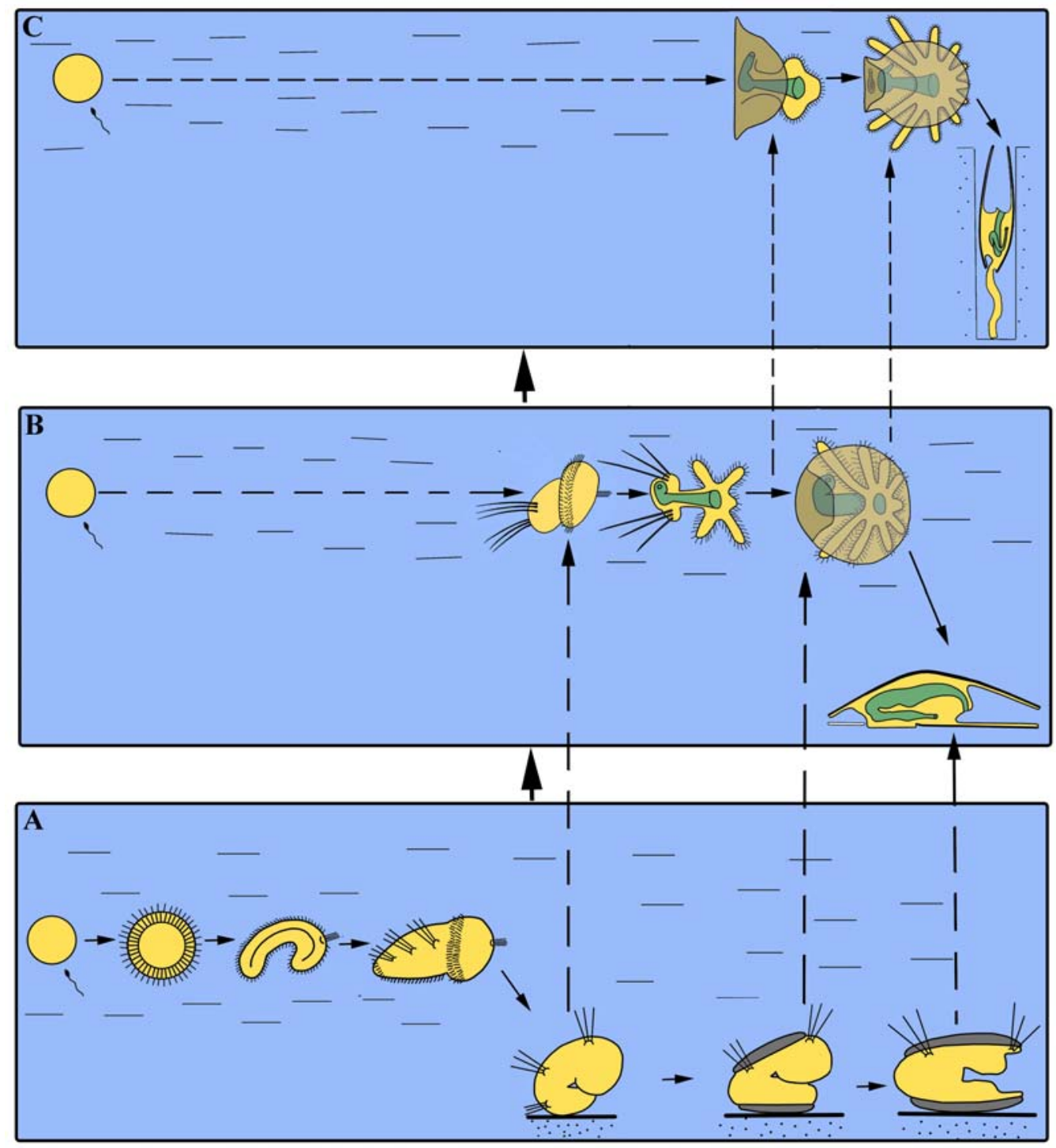

Fig. 8. Origin of the life cycles of recent discinids and lingulids. A — ancestral craniid-like life cycle; B discinid life cycle; A - lingulid life cycle.

Рис. 8. Происхождение жизненных циклов современных дисцинид и лингулид. А 一 кранииподобный жизненный цикл; В — жизненный цикл дисцинид; $\mathrm{C}$ - жизненный цикл лингулид.

egg envelope, and the shelled planktotrophic larva of lingulids corresponds to a juvenile that has developed in the water column (Fig. 8C).

In conclusion, the main points arising from the analysis of the brachiopod life cycles are as follows (Fig. 9). The ancestral brachiopod had a pelago-benthic life cycle with a ciliary plank- totrophic larva (not to be confused with the shelled planktrotophic juvenile of recent linguliforms) that folded during metamorphosis (Fig. 9). The next evolutionary stage was the transition from planktotrophy to lecithotrophy, but the lecithotrophic larvae of recent brachiopods are not homologous. Recent craniiforms retain 


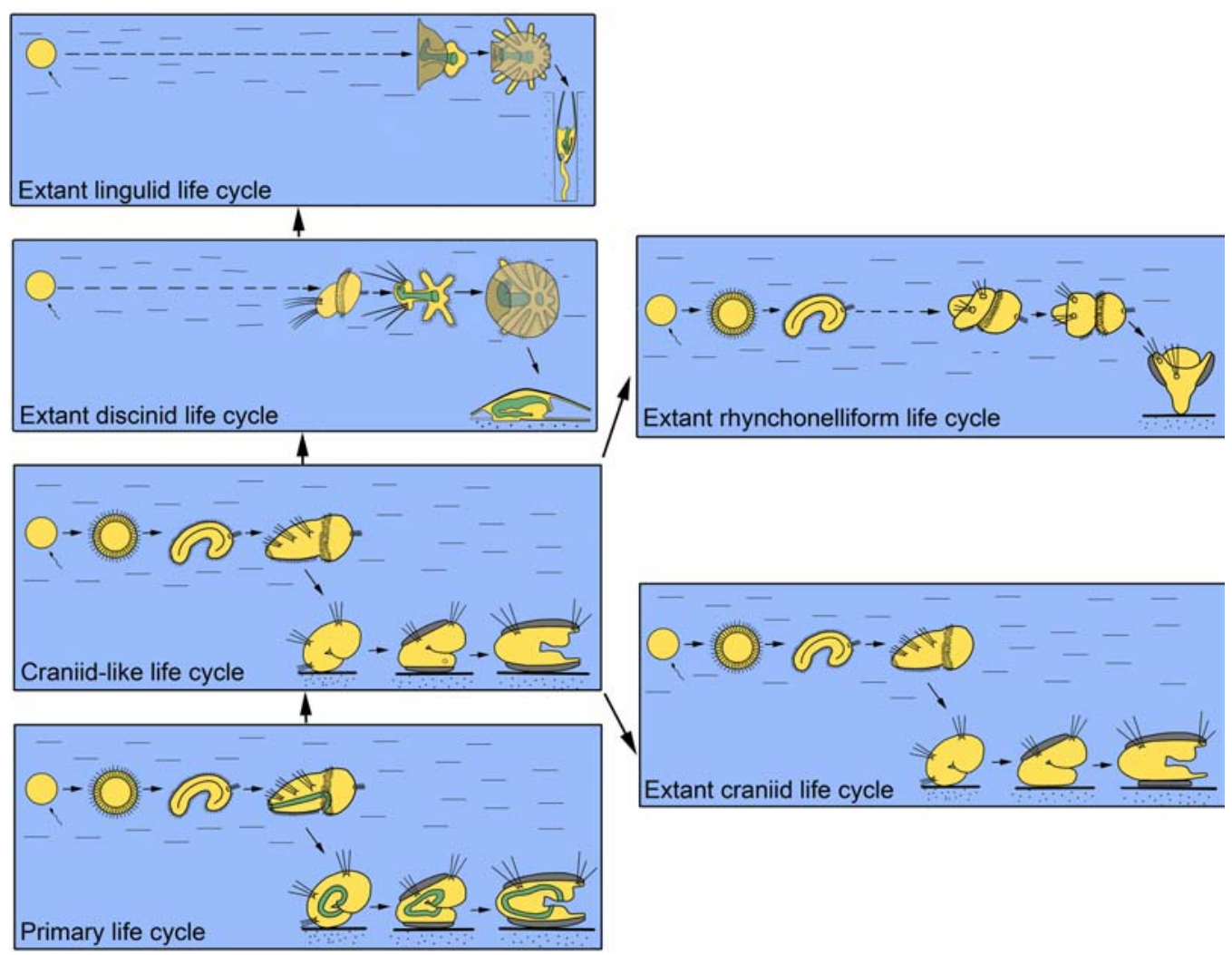

Fig. 9. Evolution of brachiopod life cycles.

Рис. 9. Эволюция жизненных циклов брахиопод.

the true unfolded lecithotrophic larva. The fullgrown lecithotrophic larva of recent rhynchonelliforms corresponds to the folded juvenile that has ascended into the water column (Fig. 9). The pelagic life cycle phase of recent discinids is comprised of a) the lecithotrophic larva that corresponds to the folded stage and b) the shelled planktotrophic stage that is essentially the juvenile ascended into the water column (Fig. 9). As for recent lingulids, their life cycle is characterized by the embryonization of all developmental stages except the shelled planktotrophic juvenile (Fig. 9). Thus, the lingulid life cycle is the most modified among all recent brachiopods.

\section{Acknowledgements}

This study was supported by the Russian Science Foundation no. 19-04-00449 (material collecting and treatment) and by the Russian
Science Foundation no. 18-14-00082 (processing of the paper). The work was performed at the Laboratory of Electronic Microscopy of M.V. Lomonosov Moscow State University under financial support of the Ministry of Education and Science of Russian Federation.

\section{References}

Altenburger A., Martinez P., Budd G.E., Holmer L.E. 2017. Gene Expression Patterns in Brachiopod Larvae Refute the "Brachiopod-Fold" Hypothesis // Front. Cell Dev. Biol. Vol.5. P.74.

Altenburger A., Wanninger A. 2009. Comparative larval myogenesis and adult myoanatomy of the rhynchonelliform (articulate) brachiopods Argyrotheca cordata, A. cistellula, and Terebratalia transversa // Front. Zool. Vol.6:3 doi:10.1186/1742-9994-6-3

Altenburger A., Wanninger A., Holmer L.E. 2013. Metamorphosis in Craniiformea revisited: Novocrania anomala shows delayed development of the ventral valve // Zoomorphology. Vol.132. No.4. P.379-387. 
Chuang S.H. 1977. Larval development in Discinisca (inarticulate brachiopod) // Am. Zool. Vol.17. P.3953.

Chuang S.H. 1996. The embryonic, larval, and early postlarval development of the terebratellid brachiopod Calloria inconspicua (Sowerby) // J. R. Soc. New Zealand. Vol.26. No.1. P.119-137.

Conklin E.G. 1902. The embryology of a brachiopod, Terebratulina septentrionalis Couthouy // Proc. Am. Philos. Soc. Vol.41. P.41-76.

Freeman G. 1993. Regional specification during embryogenesisin the articulate brachiopod Terebratalia // Dev. Biol. Vol.160. P.196-213.

Freeman G. 1995. Regional specification during embryogenesis in the inarticulate brachiopod Glottidia // Dev. Biol. Vol.172. P.15-36.

Freeman G. 1999. Regional specification during embryogenesis in the inarticulate brachiopod Discinisca // Dev. Biol. Vol.209. P.321-339.

Freeman G. 2000. Regional specification during embryogenesis in the craniiform brachiopod Crania anomala // Dev. Biol. Vol.227. P.219-238.

Freeman G. 2003. Regional specification during embryogenesis in Rhynchonelliform brachiopods // Dev. Biol. Vol.261. P.268-287.

Gąsiorowski L., Hejnol A. 2019. Hox gene expression in postmetamorphic juveniles of the brachiopod Terebratalia transversa // EvoDevo. Vol.10:1; https:// doi.org/10.1186/s13227-018-0114-1

Harper D.A.T., Popov L.E., Holmer L.E. 2017. Brachiopods: origin and early history // Paleontology. Vol.60. No.5. P.609-631.

Kovalevsky A.O. 1874. [Nablyudeniya nad razvitiem Brachiopoda (On the development of the Brachiopoda] // Izvestia Obschestva Liubiteley Estestvoznaniya, Anthropologii i Etnografii. Vol.14. P.1-40 [in Russian].

Kovalevsky A.O. 1883. Observations sur le developpement des brachiopods (Analysis by Oehlert and Deniker) // Arch. Zool. Exp. Gén. Sér. 2. P.57-76.

Long J.A., Stricker S.A. 1991. Brachiopoda // A.C. Giese, J.S. Pearse, V. Pearse (eds.). Reproduction of marine invertebrates. Pacific Grove. CA: The Boxwood Press. Vol.4. Echinoderms and Lophophorates. P.47-84.

Lüter C. 2000. The origin of the coelom in Brachiopoda and its phylogenetic significance // Zoomorphology. Vol.120. No.1. P.15-28.

Lüter C. 2001. Brachiopod larval setae - a key to the phylum's ancestral life cycle? // H. Brunton, L.R.M. Cocks, S.L. Long (eds.). Brachiopods Past and Present. Proceedings of the Millennium Brachiopod Congress,
2000. The Systematics Association. Special Volume Series 63. London: Taylor and Francis. P.46-55.

Malakhov V.V. 1976. [Certain stages of embryogenesis in Cnismatocentrum sakhaliensis parvum (Brachiopo$\mathrm{da}$, Testicardines) and the problem of evolution of the way of origin of coelomic mesoderm] // Zoologicheskii Zhurnal. Vol.55. No.1. P.66-75 [in Russian, with English summary].

Malakhov V.V. 1983. [Anatomy of the Larvae of the Articulate Brachiopod Cnismatocentrum sakhaliensis parvum] // Trudy Zoologicheskii Instituta AN SSSR. Vol.109. P.147-55 [in Russian].

Martín-Durán J.M., Passamaneck Y.J., Martindale M.Q., Hejnol A. 2016. The developmental basis for the recurrent evolution of deuterostomy and protostomy // Nature Ecology \& Evolution. Vol. 1:0005. DOI: 10.1038/s41559-016-0005.

Nielsen C. 1991. The development of the brachiopod Crania (Neocrania) anomala (O.F. Müller) and its phylogenetic significance // Acta Zool. Vol.72. No.1. P.7-28.

Nielsen C. 2001. Animal Evolution. Interrelationships among Living Phyla. New York: Oxford Univ. Press. $563 \mathrm{p}$.

Percival E. 1944. A contribution to the life-history of the brachiopod Terebratella inconspicua Sowerby // Trans. R. Soc. New Zealand. Vol.74. P.1-23.

Percival E. 1960. A contribution to the life-history of the brachiopod Teuglorhynchia nigricans // Quat. J. microsc. Sci. Vol.101. P.439-457.

Santagata S. 2015. Brachiopoda // A. Wanninger (ed.). Evolutionary Developmental Biology of Invertebrates. Wien: Springer. Vol.2. Lophotrochozoa (Spiralia). P.263-277.

Vellutini B.C., Hejnol A. 2016. Expression of segment polarity genes in brachiopods supports a non-segmental ancestral role of engrailed for bilaterians // Sci. Rep. Vol.6. No.32387. doi: 10.1038/srep32387

Williams A., Carlson S.J., Brunton C.H.C., Holmer L.E., Popov L. 1996. A supra-ordinal classification of the Brachiopoda // Philos. Trans. R. Soc. B. Vol.351. No.1344. P.1171-1193.

Yatsu N. 1902. On the development of Lingula anatina // Journal of the College of Science, Imperial University, Tokyo, Japan. Vol.17. No.4. P.1-112.

Zakrzewski A.-C., Suhb A., Lüter C. 2012. New insights into the larval development of Macandrevia cranium (Müller, 1776) (Brachiopoda: Rhynchonelliformea) // Zoologischer Anzeiger. Vol.251. No.4. P.263-269.

Responsible editor K.G. Mikhailov 